Web site: https://journal.djas.uodivala.edu.iq/

ISSN: 2073-9524 (Print)

https://dx.doi.org/10.52951/dasj.21130102

ISSN: 2310-8746 (Online)

\title{
Influence of Bio-Fertilizers and Addition Methods on Growth, Yield and Quality of Sweet Pepper Under Green House
}

\author{
S. M. Ahmed ${ }^{1}$ \\ A. J. Abdulsada \\ N. S. Deiab \\ G.K. Abbas \\ R. S. Ibrahim
}

Ministry of Science and Technology, Agricultural Research Directorate, Iraq - Baghdad. Plant Breeding \& improvement center

${ }^{1}$ Corresponding Author: Samaf-88@hotmail.com

\begin{abstract}
The effect of some biofertilizers and addition methods on growth, yield, and quality of sweet pepper were studied under greenhouse conditions. This research was conducted at ALLatifia Research Station(Located $35 \mathrm{~km}$ south of Baghdad), Agricultural Research Directorate, Baghdad- Iraq, during season 2016. The factors were methods of adding biofertilizers $(A)$ included added to seeds $\left(\mathrm{A}_{1}\right)$ and added to transplants $\left(\mathrm{A}_{2}\right)$ and bio-fertilizers (T) included without adding any biofertilizers as control $\left(\mathrm{T}_{0}\right)$, Pseudomonas fluorescence $\left(\mathrm{T}_{1}\right)$, Azospirillim brasilense $\left(\mathrm{T}_{2}\right)$, Bacillus subtillus $\left(\mathrm{T}_{3}\right)$ and Azotobactor chroococcum $\left(\mathrm{T}_{4}\right)$. Results showed a significant increase in plant height for treatment of Azotobacter chroococcum which recorded $(79.00 \mathrm{~cm})$ compared with $(65.00 \mathrm{~cm})$ in the control treatment. There is no significant influence of biofertilizers treatments in leaf area $\mathrm{dcm}^{2}$. Moreover, the treatment of Azotobacter chroococcum showed a significant increase for plant yield and total yield which recorded (1344.00 gm plant ${ }^{-1}$ and $1512.00 \mathrm{~kg}_{\text {green }}$ house $\mathrm{ge}^{-1}$ ) respectively in comparison with the control treatment which recorded( $880.00 \mathrm{gm} \mathrm{plant}^{-1}$ and $989.00 \mathrm{~kg}$ green house $^{-1)}$ respectively.
\end{abstract}

Keywords: Biofertilizers, Sweet Pepper, Growth, Yield.

\section{Introduction}

Sweet pepper (Capsicum annuum L.) is a major vegetable crop in Iraq, tropical, subtropical, and all parts of the world because of its economic and nutritional value for human health (Matlob et al, 1989). Othman (2007) indicated to an increase in the rates of chemical fertilizers use when planting vegetable compared with other crops because they were planted more than once in one season, although chemical fertilizers have important role in crop production excessive use it appeared many problems and caused harmful effects on health and the environment pollution. Has been to use of biofertilizers a significant impact on obtaining crops that are highly productive and free from chemical pollutants due to its ability to inhibit and stop the growth of pathogenic microorganisms and its ability to stimulate and increase root and vegetative growth and increase the absorption of nutrients essential for growth and increase the plant's ability to resist unsuitable environmental conditions (Al-Shahat, 2007). Al-Dulaimi et al (2003) explained that the use of the Pseudomonas fluorescence has increased the growth of tomato plants under Greenhouse conditions. Shams (2003) showed that when using Nitropin (contains three different nitrogen fixers of the Azotobacter, Azosprillium, and Bacillus ) and phosphorin (Biofertilizer containing a bacterial strain of Bacillus megatherium var phosphaticum, It has the ability to convert Tricalcium phosphate) with different levels of

\section{Dates:}

Received: 01 March 2021
Accepted 27 April 2021
Published: 30 June 2021 
nitrogen and phosphorus, gave an increasing in plant length, stem thickness, number of leaves, leaf area, dry plant weight and the highest content of chlorophyll a, b and total chlorophyll. Al-Samarrai and Rahi (2006) reported that the inoculated tomato seeds, Hofuf variety by Azotobacter chroococcum and Azospirillium brasilense, caused increasing in the germination rate of inoculated seeds and root lengths of the plants. Fawzy et al (2012) also indicated that the use of Azotobacter with Ascorbic Acid with a concentration of $400 \mathrm{mg} . \mathrm{L}^{-1}$ spraying on pepper plant achieved a significant increase in plant height, number of branches, number of fruits, and yield. El-Hifny and El-Sayed (2011) found that inoculated of sweet pepper plants with the microbin (Biofertilizers containing Azotobacter and Azospirillium) resulted in a significant increase in the length and diameter of the fruit and the total yield and the content leaves of the chlorophyll a, total chlorophyll and the fruit content of the vitamin $\mathrm{C}$ . Zehra et al (2012) indicated that inoculated of hot pepper plants with biological nitrogen stabilizers individually or in combination with the addition of different levels of mineral nitrogen led to significant differences in the growth and yield characteristics. Alwan (2016) found that the addition of biofertilizers on soil gave increasing in chlorophyll content, dry weight of vegetative and the total yield compared with control treatment of beans plant. In another study, using Azospirillium with 25\% FYM (Farm Yard Manure) gave increasing in plant yield and total yield compared with control treatment (Meena et al, 2017). Therefore, this study aimed to evaluate the effect of some biofertilizers and addition methods on the growth, yield, and quality of sweet pepper under Greenhouse conditions.

\section{Materials and Methods}

This research was conducted at AL-Latifia research station(Located $35 \mathrm{~km}$ south of Baghdad. E $44.16^{\circ}$ and N 33.03 ${ }^{\circ}$ ), Agricultural Research Directorate, Ministry of Science and Technology Baghdad - Iraq during season 2016, using the Olympic sweet pepper cultivar.

\section{Prepare seeds and transplants}

\section{1 - Treatment of seeds}

Pepper seeds were treated with biofertilizer by coating them with the bacterial suspension for 10 minutes and then let to dry for 15 minutes (a gram of bacterial incoula contains 80-100 x $103 \mathrm{cfu} / \mathrm{gm}$ incoula). The treated and untreated seeds were planted on 7/10/2016 in transplanting trays which contain peat moss and the trays were kept inside the greenhouse for germination before transferring to the permanent place (Deiab, 2012).

\section{2 - Treatment of transplants}

Pepper seeds were sown in transplanting trays that contain peat moss on $7 / 10 / 2016$. Biofertilizers were added to pepper transplants when real leaf appeared on $31 / 10 / 2016$ at a rate of $5 \mathrm{ml}$ of the bacterial suspension for each transplant (a gram of bacterial incoula contains $80-100 \times 103 \mathrm{cfu} / \mathrm{gm}$ incoula). The trays were placed in the Greenhouse until transferring to the permanent place (Deiab, 2012).

\section{Preparing the Greenhouse}

The plastic house was prepared with a distance of $9 \times 50 \mathrm{~m}$ and solar sterilization was applied from 15 June until 1 September 2016 and then divided into five blocks with a length of $50 \mathrm{~m}$ and width of $0.80 \mathrm{~m}$ and a distance between raw and other 0.80 $\mathrm{m}$ with $1 \mathrm{~m}$ left on each side. Each block was divided into 9 sections of $5 \mathrm{~m}$ each experimental unit, pepper transplants were planted with a distance of $0.40 \mathrm{~m}$ between plants on 12/11/2016. 
Chemical fertilizer was added as $\mathrm{KNO}_{3}$ potassium nitrate at a rate of $142 \mathrm{~kg}$ and 190 $\mathrm{kg} \cdot \mathrm{ha}^{-1}$ in four times during the growing season, Two weeks after transferring the seedlings to the plastic house, pre-flowering, flowering stage, and after fruits set (Shams,2003). The Greenhouse soil has been characterized physically and chemically as shown in Table (1). The temperature and humidity were measured with a Thermo hygro graph, the temperature was ranged between 35-37 during the day and 10midnight, and the humidity was between $80-85 \%$. The factorial experiment was laid out in Randomized Complete Block Design (R.C.B.D) with three replicates. Means of traits were compared by L.S.D. at level 5\% (Al-Sahuki and Wahib, 1990). The data were analyzed using Statistical Analysis System GenStat ed ${ }^{12}$ (Glaser and Biggs, 2010)

Table 1. Physical and Chemical properties of Greenhouse Soil

\begin{tabular}{|c|c|c|c|}
\hline \multicolumn{2}{|c|}{ properties } & Standard unit & value \\
\hline \multicolumn{2}{|c|}{$\mathrm{pH}_{1: 1}$} & --- & 7.8 \\
\hline \multicolumn{2}{|c|}{$\mathrm{EC}_{1: 1}$} & $\mathrm{dSm}^{-1}$ & 4.2 \\
\hline \multicolumn{2}{|c|}{ Organic matter } & $\mathrm{gkg}^{-1}$ & 0.70 \\
\hline \multicolumn{2}{|c|}{$\mathrm{HCO}_{3}$} & $\mathrm{gkg}^{-1}$ & 2.45 \\
\hline \multicolumn{2}{|c|}{ Available Nitrogen } & $\mathrm{mgkg}^{-1}$ & 46.20 \\
\hline \multicolumn{2}{|c|}{ Available Phosphorus } & $\mathrm{mgkg}^{-1}$ & 20.83 \\
\hline \multicolumn{2}{|c|}{ Available potassium } & $\mathrm{mgkg}^{-1}$ & 189.0 \\
\hline Ions & $\mathrm{Mg}^{+2}$ & $\mathrm{mgL}^{-1}$ & 33.96 \\
\hline soluble & $\mathrm{Ca}^{+2}$ & $\mathrm{mgL}^{-1}$ & 110.2 \\
\hline \multicolumn{2}{|c|}{ silt } & $\mathrm{gkg}^{-1}$ & 490 \\
\hline \multicolumn{2}{|c|}{ clay } & $\mathrm{gkg}^{-1}$ & 140 \\
\hline \multicolumn{2}{|c|}{ sand } & $\mathrm{gkg}^{-1}$ & 370 \\
\hline \multicolumn{2}{|c|}{ Soil texture } & Loam & \\
\hline
\end{tabular}

\section{Prepare biofertilizers}

Biofertilizers were obtained from the Center of Biotechnology / Agricultural Research Directorate. Ministry of Science \&Technology, Baghdad, Iraq.

\section{Treatments}

\section{Treatments included:}

1- Methods of Addition inocula (A)

$\mathrm{A}_{1}$ : Add the inocula to seeds

$\mathrm{A}_{2}$ : Add the inocula to the transplants

\section{The biofertilizers $(T)$ included}

$\mathrm{T}_{0}$ : control (without biofertilizers )

$\mathrm{T}_{1}$ : Pseudomonas fluorescence

$\mathrm{T}_{2}$ : Azospirillum brasilense

$\mathrm{T}_{3}$ : Bacillus subtilis

$\mathrm{T}_{4}$ : Azotobacter chroococcum 


\section{Parameters of vegetative growth and yield}

Parameters were studied by randomly selected 5 plants in each treatment. The vegetative growth measurements were recorded after 55 days from planting and included the plant height $(\mathrm{cm})$, stem diameter $(\mathrm{mm})$ and several branches per plant, fresh weight of root and shoot, the relative content of chlorophyll was measured by Chlorophyll meter SPAD - 502 according (Minnotti et al, 1994), leaf area $\left(\mathrm{dcm}^{2}\right)$ measured by the Portable Leaf Area Meter according to (Tekalign and Hammes, 2005), The yield characteristics were recorded weekly after 30 days from plantings and included an average number of fruits (fruit per plant), average fruit weight (gm), fruit size $\left(\mathrm{cm}^{3}\right)$ and an average yield of one plant $(\mathrm{kg})$ were taken. As for calculating the yield on basis of the Green house, it was done on basis that the house contains 625 plants (the distance between the plant and another is $0.40 \mathrm{~m}$ and the length of the planting line is $50 \mathrm{~m}$ ). Therefore, the yield of plant for each treatment multiplied by 625 plants equals total yields of Greenhouse, length, and diameter of fruit were taken to measure per plant.

\section{Results and Discussions}

\section{Effect of biofertilizers on the growth of pepper}

The results of Table 2 showed the effect of methods of inocula addition was significant differences in plant height $(\mathrm{cm})$. Transplants treatment $\left(\mathrm{A}_{2}\right)$ gave the highest significant differences $(\mathrm{P}<0.05)$ in plant height $(78.70 \mathrm{~cm})$ compared with $\left(\mathrm{A}_{1}\right)$ seed treatment which reached $(68.70 \mathrm{~cm})$. Biofertilizer treatments, results showed that $\mathrm{T}_{4}$ treatment (A. Chroococcum) was significantly higher than $(79.00 \mathrm{~cm})$ and followed by $\mathrm{T} 2$ treatment ( $A$ brasilense ) was $(77.50 \mathrm{~cm})$ compared with $\mathrm{T}_{0}$ treatment (without Bio-fertilizer) which gave $(65.00 \mathrm{~cm})$. Interaction between addition methods $(\mathrm{A})$ and biofertilizer treatments $(\mathrm{T})$ had a significant effect $\mathrm{A}_{2} \mathrm{~T}_{4}$ (transplants + A. Chroococcum ) treatment gave $(85.70 \mathrm{~cm})$, while A1T0 treatment addition methods of biofertilizers to seeds + without adding biofertilizers gave (61.70 $\mathrm{cm})$. The same table showed also significant differences in the diameter of stem between the method of additional treatments, transplant treatment $\left(\mathrm{A}_{2}\right)$ there was significantly superior $16.80 \mathrm{~mm}$ compared with seeds treatment $\left(\mathrm{A}_{1}\right)$ which gave $15.47 \mathrm{~mm}$. The results showed significant differences in the effect of biofertilizer treatments on stem diameter where A. Chroococcum treatment $\left(\mathrm{T}_{4}\right)$ was significantly superior which reached $(17.00 \mathrm{~mm})$ and reduced significantly without adding biofertilizer treatment $\left(\mathrm{T}_{0}\right)$ which reached14.50 $\mathrm{mm}$. The interaction between the methods of inocula addition and biofertilizers treatments had a significant effect the highest stem diameter was in $\mathrm{A}_{2} \mathrm{~T}_{4}$ and $\mathrm{A}_{2} \mathrm{~T}_{1}$ treatments which gave $(18.00 \mathrm{~mm})$, while the least stem diameter was in the method of adding biofertilizers to the seeds + without adding biofertilizers treatment $\left(\mathrm{A}_{1} \mathrm{~T}_{0}\right)$ which gave $14.33 \mathrm{~mm}$ (Table 2$)$ 
Table 2. Effect of Biofertilizers and Addition Methods on Plant Height (cm) and Stem Diameter $(\mathrm{mm})$ of Sweet Pepper under Greenhouse Conditions

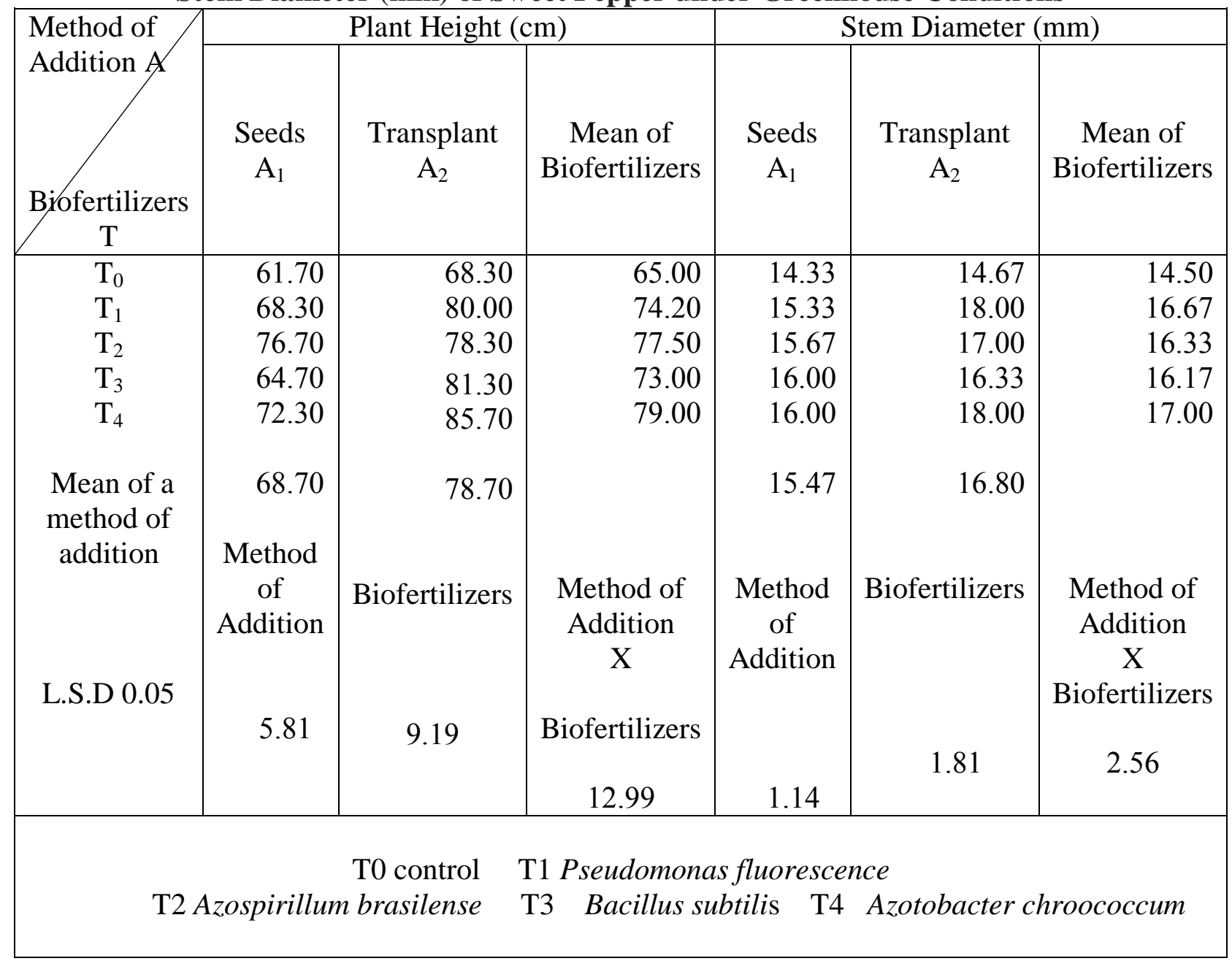

Data of Table 3 showed no significant differences between addition methods of biofertilizers (A) in several branches per plant. Biofertilizer treatments gave the highest rate of branches per plant in $\mathrm{T}_{4}$ treatment which reached ( 6.50 branches per plant) compared with 4.33 branches per plant for treatment $\mathrm{T}_{0}$. Interaction between methods of inocula addition and biofertilizer treatments showed significant effect between treatments $\mathrm{A}_{2} \mathrm{~T}_{4}$ treatment gave the highest number of branches (7.00) while the lowest number of branches was recorded with $\mathrm{A}_{1} \mathrm{~T}_{0}$ treatment which reached (4.00).

Moreover, the results of Table 3 showed a significant effect between the method of incoula addition biofertilizers in fresh weight of shoot the treatment of transplants ( $\mathrm{A}_{2}$ ) had the highest fresh weight of shoot (233.70 gm) compared with the treatment of seeds A1 which gave (137.10 gm). For biofertilizers treatments, a significant effect on shoot weight was found in $\mathrm{T}_{4}$ treatment which recorded the highest shoot weight (205.90 g) while $\mathrm{T}_{0}$ treatment gave the lowest shoot weight (133.60 gm). Interaction between methods of incoula addition biofertilizers and biofertilizer showed significant effect the best treatments were $\mathrm{A}_{2} \mathrm{~T}_{1}$ which gave (303.30 gm shoot fresh weight), while the lowest shoot fresh weight was in $\left(\mathrm{A}_{1} \mathrm{~T}_{0}\right)$ treatment which gave $(130.50 \mathrm{~g}$ shoot fresh weight). 
Table 3. Effect of Biofertilizers and Addition Methods on the Number of Branches and Fresh Weight of Shoot (g) of the Sweet Pepper under Greenhouse Conditions

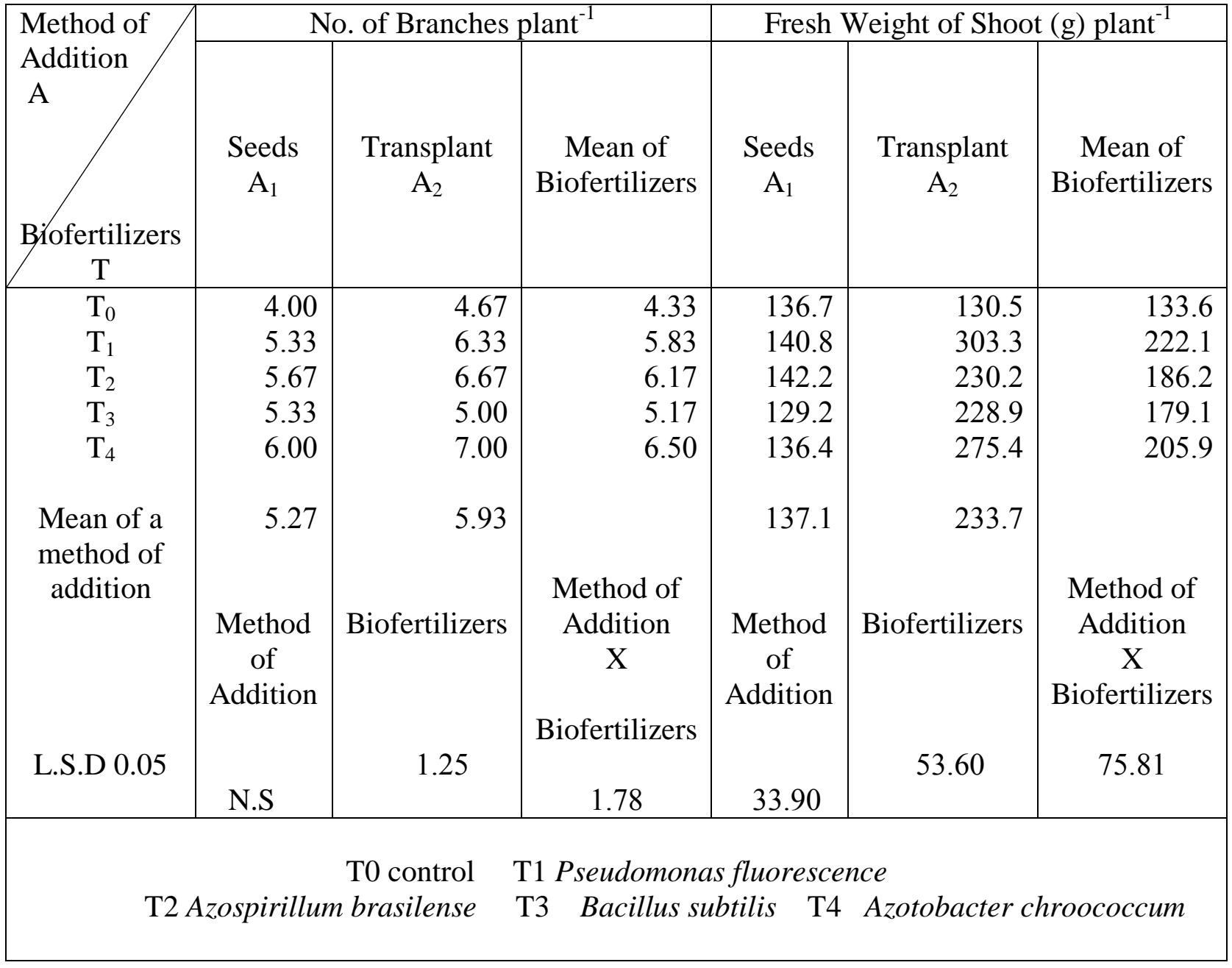

The results of Table 4 showed no significant differences in fresh weight of roots between methods of inocula addition, among biofertilizers treatments and the interaction between them. The results of the same table also indicated no significant differences in chlorophyll content in leaves between the two methods of inocula addition there were significant differences among biofertilizers treatments on chlorophyll content where $\mathrm{T}_{4}$ treatment was significantly superior which reached (49.07 SPAD units) and reduced significantly in $\mathrm{T}_{0}$ treatment (40.40 SPAD units). The interaction between the methods of inocula addition and biofertilizer treatments had a significant effect $\mathrm{A}_{2} \mathrm{~T}_{4}$ treatment (transplants + A. Chroococcum) gave the highest amount of chlorophyll (50.97 SPAD units), while $\mathrm{A}_{1} \mathrm{~T}_{0}$ treatment gave (40.30 SPAD units). 
Table 4. Effect of Biofertilizers and Addition Methods on the Weight Roots of the Plant and the Percentage of Chlorophyll of the Sweet Pepper under

Greenhouse Conditions

\begin{tabular}{|c|c|c|c|c|c|c|}
\hline \multirow{2}{*}{$\begin{array}{l}\text { Method of } \\
\text { Addition } \\
\mathrm{A} \\
\text { Biofertilizers } \\
\mathrm{T}\end{array}$} & \multicolumn{3}{|c|}{ Fresh Weight of Root $(\mathrm{g})$ plant $^{-1}$} & \multicolumn{3}{|c|}{ Relative Chlorophyll Content } \\
\hline & $\begin{array}{c}\text { Seeds } \\
\mathrm{A}_{1}\end{array}$ & $\begin{array}{c}\text { Transplant } \\
\mathrm{A}_{2}\end{array}$ & $\begin{array}{c}\text { Mean of } \\
\text { Biofertilizers }\end{array}$ & $\begin{array}{c}\text { Seeds } \\
\mathrm{A}_{1}\end{array}$ & $\begin{array}{c}\text { Transplant } \\
\mathrm{A}_{2}\end{array}$ & $\begin{array}{c}\text { Mean of } \\
\text { Biofertilizers }\end{array}$ \\
\hline $\begin{array}{c}\mathrm{T}_{0} \\
\mathrm{~T}_{1} \\
\mathrm{~T}_{2} \\
\mathrm{~T}_{3} \\
\mathrm{~T}_{4} \\
\text { Mean of a } \\
\text { method of } \\
\text { addition } \\
\text { L.S.D } 0.05\end{array}$ & $\begin{array}{l}28.80 \\
31.40 \\
34.60 \\
28.40 \\
32.30 \\
\\
31.10\end{array}$ & $\begin{array}{l}26.00 \\
37.10 \\
36.40 \\
32.70 \\
38.00 \\
\\
34.00\end{array}$ & $\begin{array}{c}\text { Method of } \\
\text { Addition } \\
\text { X } \\
\text { Biofertilizers } \\
\text { N.S }\end{array}$ & $\begin{array}{l}40.30 \\
46.83 \\
46.23 \\
44.50 \\
47.17 \\
45.01\end{array}$ & $\begin{array}{l}40.50 \\
46.27 \\
49.27 \\
47.53 \\
50.97 \\
46.91\end{array}$ & $\begin{array}{c}\text { Method of } \\
\text { Addition } \\
\mathrm{X} \\
\text { Biofertilizers } \\
8.84\end{array}$ \\
\hline & spirillı & $\begin{array}{l}\text { T0 control } \\
\text { brasilense }\end{array}$ & $\begin{array}{l}\text { T1 Pseudomor } \\
\text { T3 Bacillus }\end{array}$ & $\begin{array}{l}\text { fluoresce } \\
\text { btilis } \mathrm{T} 4\end{array}$ & $\begin{array}{l}\text { Azotobacter } \\
\text { Azoto }\end{array}$ & hroococcum \\
\hline
\end{tabular}

The results of Table 5 showed no significant differences between addition methods among biofertilizers treatments and interaction between them on leaf area $\left(\mathrm{dcm}^{2}\right)$.

Table 5. Effect of Biofertilizers and Addition Methods on Leaf Area $\mathrm{dcm}^{2}$ of Sweet Pepper under Greenhouse Conditions

\begin{tabular}{|l|c|c|c|}
\hline \multirow{2}{*}{$\begin{array}{l}\text { Method of } \\
\text { Addition A }\end{array}$} & \multicolumn{3}{|c|}{ Leaf Area $\mathrm{dcm}^{2}$ plant $^{-1}$} \\
\cline { 2 - 4 } & Seeds & Transplant & Mean of \\
Biofertilizers & $\mathrm{A}_{1}$ & $\mathrm{~A}_{2}$ & Biofertilizers \\
\hline & & & \\
\hline
\end{tabular}




\begin{tabular}{|c|c|c|c|}
\hline $\begin{array}{c}\text { Mean of a method of } \\
\text { addition }\end{array}$ & $\begin{array}{r}31.30 \\
33.90 \\
38.10 \\
35.40 \\
46.60 \\
\\
37.10 \\
\text { Method of } \\
\text { Addition } \\
\\
\text { N.S }\end{array}$ & $\begin{array}{r}38.30 \\
48.40 \\
46.30 \\
42.50 \\
34.90 \\
\\
42.10 \\
\text { Biofertilizers } \\
\\
\\
\\
\text { N.S }\end{array}$ & $\begin{array}{l}\text { Method of } \\
\text { Addition } \\
\text { X } \\
\text { Biofertilizers } \\
\text { N.S }\end{array}$ \\
\hline $\begin{array}{r}\text { T0 } \\
\text { T2 Azospir }\end{array}$ & $\begin{array}{l}\text { rol } \mathrm{T} 1 \text { Pseuc } \\
\text { a brasilense } \\
\text { chrooc }\end{array}$ & $\begin{array}{l}\text { nonas fluorescenc } \\
\text { Bacillus subtil } \\
\text { cum }\end{array}$ & T4 Azotobacter \\
\hline
\end{tabular}

The increase in most shoot characteristics of plants with biofertilizers inoculation (Azotobacter and Azospirillum) attributed to the role of biofertilizers in the availability, absorption, and concentration of nutrients such as nitrogen and phosphorus. Biofertilizers also play a role in stimulating the production of growth regulators, which are positively reflected in the increased division, elongation, and expansion of cells, which reflected on shoot growth (Mirzakhan et al, 2009; Salhia, 2010; Allawi, 2013; Shash et al, 2018 ), and availability of elements in leaves lead to increase management and activity of photosynthesis, which leads to increase $\mathrm{CO}_{2}$ in the leaves, which is the basic unit for building carbohydrates, amino acids and proteins structure and therefore increasing vegetative growth ( Latitha et al, 2004; Jark et al, 2010; Taiz and Zeiger, 2010 ). The results of the present study were in agreement with many papers (Fawzy et al, 2012; Dharmendra, 2014; Saeed et al, 2014; Meena et al, 2017 ).

\section{Effect of biofertilizers on yield of pepper}

Table 6 indicated that the methods of inocula addition gave a significant difference in the number of fruits per plant. A significantly higher number of fruits per plant was recorded in transplants treatment $\mathrm{A}_{2}$ was (24.40 fruit Plant ${ }^{-1}$ ) while the seed treatment $A_{1}$ gave (21.67 fruit Plant ${ }^{-1}$ ). Biofertilizer application $T_{2}$ and $T_{4}$ treatments recorded higher fruits and reached (24.67and 24.33fruits. Plant ${ }^{-1}$ ) respectively, compared with the $\mathrm{T}_{0}$ treatment (without biofertilizers) which gave (20.50 fruit. Plant ${ }^{-1}$ ).

Interaction between the methods of inocula addition and biofertilizers application showed a significant effect $\mathrm{A}_{2} \mathrm{~T}_{4}$ and $\mathrm{A}_{2} \mathrm{~T}_{2}$ treatments gave (27.33 and 26.00 fruits. Plant $^{-1}$ ) respectively, while $\mathrm{A}_{1} \mathrm{~T}_{0}$ treatment gave (20.33) fruits. The same table showed a significant effect in the fruit weight of Greenhouse according to the methods of inocula addition which reached $53.90 \mathrm{gm}$ in treatment of transplants $\left(\mathrm{A}_{2}\right)$ compared 
with the treatment of seeds $\left(A_{1}\right)$ which gave $(46.30 \mathrm{gm})$. Biofertilizer treatments $\mathrm{T}_{4}$ was superior in fruit weight which recorded $(54.70 \mathrm{gm})$ compared with others and $\mathrm{T}_{0}$ treatment gave the lowest value $(43.00 \mathrm{gm})$. Interaction between the methods of inocula addition and biofertilizer treatments found significant differences among treatments the highest value recorded for treatments $A_{2} T_{4}$ and $A_{2} T_{3}$ were $(58.00 \mathrm{gm})$ for both of them while the lowest yield was recorded by $A_{1} T_{0}$ treatment which reached $(41.70 \mathrm{gm})$.

Table 6. Effect of Biofertilizers and Addition Methods on Number of Fruits and Fruit Weight of Sweet Pepper under Greenhouse Conditions

\begin{tabular}{|c|c|c|c|c|c|c|}
\hline Method of & & No.of Fruits pl & $a t^{-1}$ & & Fruit Weight(g & m) \\
\hline $\begin{array}{c}\mathrm{A} \\
\mathrm{T}\end{array}$ & $\begin{array}{c}\text { Seeds } \\
\mathrm{A}_{1}\end{array}$ & $\begin{array}{c}\text { Transplant } \\
\mathrm{A}_{2}\end{array}$ & $\begin{array}{c}\text { Mean of } \\
\text { Biofertilizers }\end{array}$ & $\begin{array}{l}\text { Seeds } \\
\mathrm{A}_{1}\end{array}$ & $\begin{array}{c}\text { Transplant } \\
\mathrm{A}_{2}\end{array}$ & $\begin{array}{c}\text { Mean of } \\
\text { Biofertilizers }\end{array}$ \\
\hline $\begin{array}{c}\mathrm{T}_{0} \\
\mathrm{~T}_{1} \\
\mathrm{~T}_{2} \\
\mathrm{~T}_{3} \\
\mathrm{~T}_{4} \\
\text { Mean of a } \\
\text { method of } \\
\text { addition } \\
\text { L.S.D } 0.05\end{array}$ & $\begin{array}{l}20.33 \\
22.33 \\
23.33 \\
22.33 \\
21.33 \\
\\
21.93\end{array}$ & $\begin{array}{l}20.67 \\
24.33 \\
26.00 \\
23.67 \\
27.33 \\
\\
\end{array}$ & $\begin{array}{c}\text { Method of } \\
\text { Addition } \\
\quad \mathrm{X} \\
\text { Biofertilizers } \\
3.23\end{array}$ & $\begin{array}{l}41.70 \\
43.70 \\
48.30 \\
47.30 \\
51.30 \\
46.50\end{array}$ & $\begin{array}{l}44.30 \\
52.70 \\
56.70 \\
58.00 \\
58.00 \\
\\
53.90\end{array}$ & $\begin{array}{c}\text { Method of } \\
\text { Addition } \\
\mathrm{X} \\
\text { Biofertilizers } \\
10.49\end{array}$ \\
\hline & Azospir & $\begin{array}{l}\mathrm{T} 0 \text { control } \\
n \text { brasilense }\end{array}$ & $\begin{array}{l}\text { T1 Pseudomon } \\
\text { T3 Bacillus }\end{array}$ & $\begin{array}{l}\text { fluorescen } \\
\text { tilis } \mathrm{T} 4\end{array}$ & Azotobacter ch & coccum \\
\hline
\end{tabular}

The methods of inocula addition showed significant differences in plant yield (Table 7). The highest value of plant yield was obtained from inocula treatments of transplant $\left(\mathrm{A}_{2}\right)$ which was $\left(1324.00 \mathrm{gm} \mathrm{plant}^{-1}\right)$ while $\left(\mathrm{A}_{1}\right)$ treatment gave $(1015.00$ gm plant $\left.{ }^{-1}\right)$. Concerning biofertilizers treatments, the results showed that $\mathrm{T}_{4}$ treatment (A. Chroococcum) was significantly higher than other treatments in fruit weight per plant which reached (1344.00 gm plant ${ }^{-1}$ ) while the lowest value was for the control treatment $\left(\mathrm{T}_{0}\right)$ which reached $\left(880.00 \mathrm{gm} \mathrm{plant}^{-1}\right)$. Interaction between the methods of inocula addition and biofertilizer treatments was significant, the highest value for treatment $\mathrm{A}_{2} \mathrm{~T}_{4}$ was (1588.00 gm plant $\left.{ }^{-1}\right)$ and the lowest plant yield of fruit was recorded for $A_{1} T_{0}$ treatments which recorded (847.00 gm plant $\left.{ }^{-1}\right)$. 
Moreover, the results of Table 7 showed a significant effect in total yield of the plastic house according to methods of inocula addition which reached $(1489.00 \mathrm{Kg})$ in the treatment of transplants $\left(\mathrm{A}_{2}\right)$ compared with the treatment of seeds $\left(\mathrm{A}_{1}\right)$ which gave $(1142.00 \mathrm{Kg})$. In addition, significant differences were found among treatments for plant yield, $\mathrm{T}_{4}$ treatment (A. Chroococcum) gave the highest value $(1512.00 \mathrm{Kg}$ ) compared with other and $\mathrm{T}_{0}$ treatment (without biofertilizers) gave the lowest yield compared with others $(989.00 \mathrm{Kg})$.Interaction between the methods of inocula addition and biofertilizer treatments found to be significant with the highest value recorded for treatment $\mathrm{A}_{2} \mathrm{~T}_{4}$ which gave $(1787.00 \mathrm{Kg}$ ) while the lowest yield was recorded by $A_{1} T_{0}$ treatment which reached $(951.00 \mathrm{Kg})$.

Table 7. Effect of Biofertilizers and Addition Methods on Yield of Plant (gm) and Total yield of House (Kg) of Sweet Pepper under Greenhouse Conditions

\begin{tabular}{|c|c|c|c|c|c|c|}
\hline \multirow{2}{*}{$\begin{array}{l}\text { Method of } \\
\text { Addition } \\
\text { A }\end{array}$} & \multicolumn{3}{|c|}{ The yield of Plant (gm) } & \multicolumn{3}{|c|}{ Total Yield of House (Kg) } \\
\hline & $\begin{array}{c}\text { Seeds } \\
\mathrm{A}_{1}\end{array}$ & $\begin{array}{c}\text { Transplant } \\
\mathrm{A}_{2}\end{array}$ & $\begin{array}{c}\text { Mean of } \\
\text { Biofertilizers }\end{array}$ & $\begin{array}{l}\text { Seeds } \\
\mathrm{A}_{1}\end{array}$ & $\begin{array}{c}\text { Transplant } \\
\mathrm{A}_{2}\end{array}$ & $\begin{array}{c}\text { Mean of } \\
\text { Biofertilizers }\end{array}$ \\
\hline $\begin{array}{c}\quad \mathrm{T}_{0} \\
\mathrm{~T}_{1} \\
\mathrm{~T}_{2} \\
\mathrm{~T}_{3} \\
\mathrm{~T}_{4} \\
\text { Mean of a } \\
\text { method of } \\
\text { addition }\end{array}$ & $\begin{array}{r}847.00 \\
976.00 \\
1100.00 \\
1055.00 \\
1099.00 \\
1015.00\end{array}$ & $\begin{array}{r}913.00 \\
1271.00 \\
1475.00 \\
1371.00 \\
1588.00 \\
1324.00\end{array}$ & $\begin{array}{c}\text { Method of } \\
\text { Addition } \\
\quad \mathrm{X} \\
\text { Biofertilizers } \\
240.10\end{array}$ & $\begin{array}{r}951.00 \\
1098.00 \\
1237.00 \\
1187.00 \\
1237.00 \\
1142.00\end{array}$ & $\begin{array}{l}1028.00 \\
1430.00 \\
1659.00 \\
1542.00 \\
1787.00 \\
1489.00\end{array}$ & $\begin{array}{c}\text { Method of } \\
\text { Addition } \\
\text { X } \\
\text { Biofertilizers } \\
270.30\end{array}$ \\
\hline & Azospir & $\begin{array}{l}\mathrm{T} 0 \text { control } \\
n \text { brasilense }\end{array}$ & $\begin{array}{l}\text { T1 Pseudomo } \\
\text { T3 Bacillus }\end{array}$ & $\begin{array}{l}\text { luoresce } \\
\text { ilis } \quad \mathrm{T} 4\end{array}$ & te & coccum \\
\hline
\end{tabular}

The results of Table 8 showed significant differences in length of fruit by methods of inocula addition wherein transplants treatment $\left(\mathrm{A}_{2}\right)$ reached $(4.88 \mathrm{~cm})$ compared with the seed treatment $\left(A_{1}\right)$ which gave $(4.28 \mathrm{~cm})$. Significant effect among biofertilizer had been found the highest rate of fruit length was in $\left(T_{2}\right)$ treatment $(4.66 \mathrm{~cm})$ and the lowest fruit length was in $\left(\mathrm{T}_{0}\right)$ treatment $(4.20 \mathrm{~cm})$. Interaction between the methods of inocula addition and biofertilizer treatments showed significant effect $\mathrm{A}_{2} \mathrm{~T}_{2}$ treatment gave $(5.43 \mathrm{~cm})$ fruit length while reduced to $(4.20$ 
$\mathrm{cm}$ ) in $\mathrm{A}_{1} \mathrm{~T}_{0}$ and $\mathrm{A}_{2} \mathrm{~T}_{0}$ treatments. The diameter of fruit in Table (8) was significantly different depending on the methods of inocula addition, transplants treatment $\left(\mathrm{A}_{2}\right)$ recorded $(53.50 \mathrm{~mm})$ compared with seeds treatment $\left(\mathrm{A}_{1}\right)$ which gave $(40.10 \mathrm{~mm})$. Also, bio-fertilizers treatments showed a significant effect on fruit diameter and the results showed that $\mathrm{T}_{4}$ treatment (A. Chroococcum) was the highest value $(50.40 \mathrm{~mm})$, while the lowest fruit diameter was in the control treatment $(38.80 \mathrm{~mm})$. Interaction between the methods of inocula addition and biofertilizer treatments showed a significant effect on fruit diameter $\mathrm{A}_{2} \mathrm{~T}_{2}$ treatment gave the highest value $(60.10 \mathrm{~mm})$ while the lowest value was in $\mathrm{A}_{1} \mathrm{~T}_{0}$ treatment $(37.40 \mathrm{~mm})$.

Table 8. Effect of Biofertilizers and Addition Methods on Length (cm) and Diameter of Fruit (mm) of Sweet Pepper under the Greenhouse Conditions

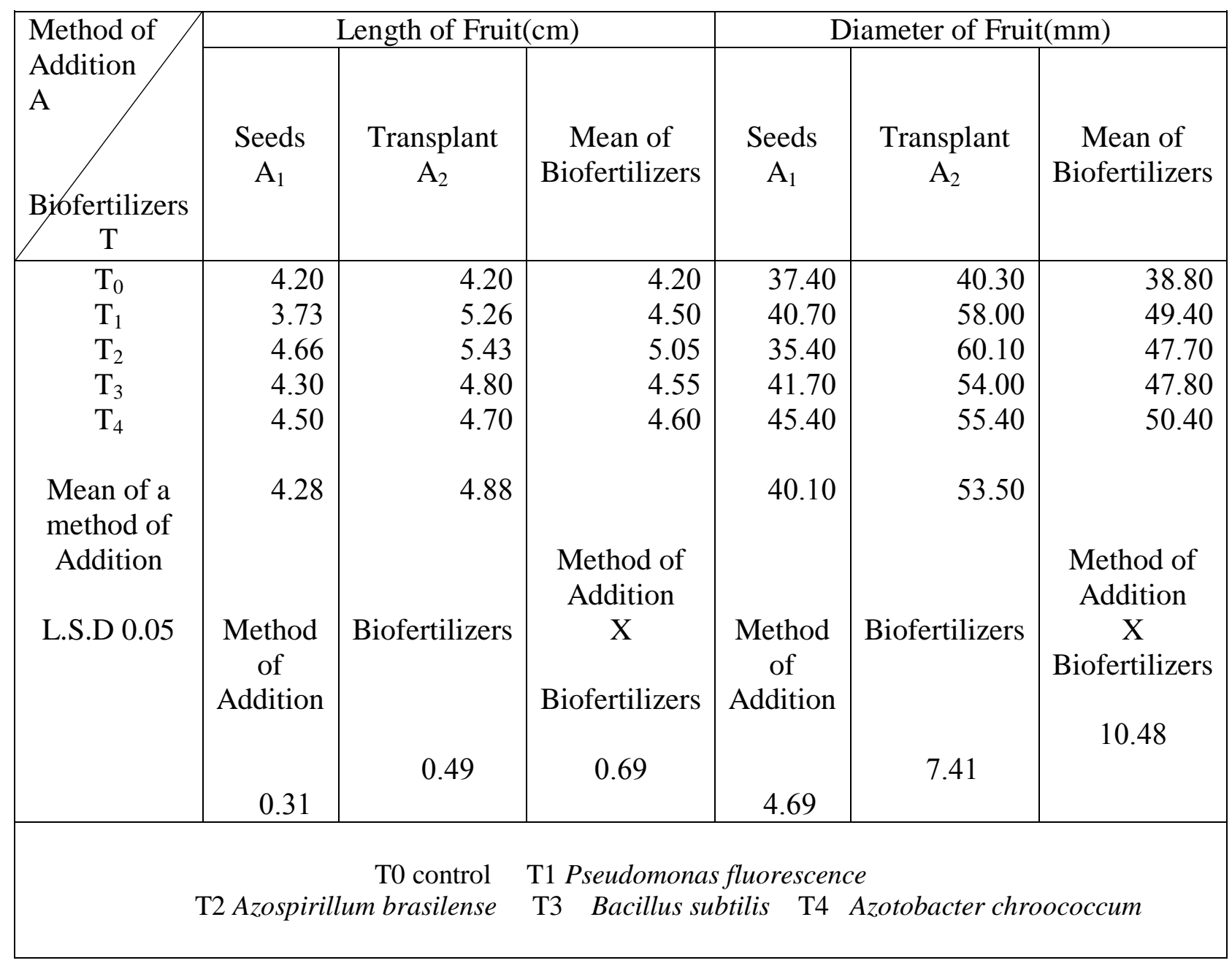

The inoculation of sweet pepper with biofertilizers leads to encouragement and increase of growth indicators through the strategies which are used in this biological system, especially the availability of nutrients through phosphorus soluble and nitrogen fixation in soil and increase the resistance of plants to biotic and abiotic stresses and production of different growth regulators like IAA and $\mathrm{GA}_{3}$. All these factors contributed to increasing lengths and diameters of fruits, the number of fruits, and weight of fruit, which lead to increased plant growth and total yield (Saharan and Nehra, 2011; Dharmendra, 2014; Saeed, 2015; Tosi et al, 2016; Shashi et al, 2018). 
The growth regulators also contribute to increasing shoot and root growth due to the division and elongation of cells and tissues.

\section{Conclusions}

In this study, bio-fertilizers showed a significant effect on most traits, Azotobacter and Azospirillum applications showed positive results in increasing the fruit yield of Sweet Pepper. Also, results revealed that treatments of transplants with biofertilizers were superior on most traits compared with treatments of seeds coating with biofertilizers.

\section{Conflict of interests}

The authors declare no conflict of interest.

\section{Acknowledgments}

The authors would like to express their sincere thanks to Dr. Shatha Y.A, Dr. Faleh .H.S. for their encouragements in achieving this work, without their great advices this work did not completed.

\section{References}

Al-Dulaimi, A.J ., S. M. Ahmed and S. A . Musa. 2003 . Development and evaluating formula of Pseudomonas fluorescens. Iraqi journal agriculture (Special Issue). 8 (3): $104-110$.

Allawi, M. M. 2013. Impact of bio,organic and chemical fertilization on the roots architectural and growth and yield of pepper plant (Capsicum annuum L.) Ph.D . Thesis. Horticulture and Landscape Department .College of Agriculture., University of Baghdad, Iraq .p:168

Al- Samarrai, I. K and H. S. Rahi . 2006. Effect of inoculation with Azotobacter and Azosperillium bacteria on the absorption of some nutrients, the concentration of plant hormones, and the growth of tomato transplantss. Iraqi Journal of Agricultural Sciences. 37 (3): 27-32.

Al-Sahuki, M. M and K. Wahib . 1990. Applications in the Design and Analysis of Experiments. Dar Al Hekma for Printing \& Publishing. Mosul. University of Al Mosul. Ministry of Higher Education and Scientific Research. Iraq.

Al-Shahat, M. R. T. 2007. Bio fertilizers and Organic Farming: Healthy Food and a Clean Environment. Cairo, Dar al-Fikr al-Arabi .p: 200 .

Alwan , U. A., M. A. Hadi and H. M. Bayan. 2016. Effect of biofertilizers and salicylic acid on availability of some nutrients in soil and plant and som vegetative and production quality of beans irrigated with saline water .Iraqi Journal of Agricultural Sciences.47(1):291 -302.

. Deiab , N. S. 2012. Utilization of Rock and Super Phosphate and Addition of Fungal and Bacterial Bio-fertilizer on Growth and Yield Potato. PhD Thesis. 
Horticulture and Gardening Engineering Department / College of Agriculture University of Baghdad. Iraq .p;150

Dharmendra, S. 2014. Effect of Organic Manures and Bio fertilizers on Growth, Yield and Quality of tomato (Solanum lycopersicum L.) .MSc. Thesis (Agriculture) .Department of Horticulture, College of Agriculture. Jawaharlal Nehru Krishi Vishwa Vidyalaya, Jabalpur.India.p:13.

Fawzy , Z.F., A.M. El-Bassiony., L. Yunsheng ., O. Zhu and A.A. Ghoname . 2012. Effect of mineral, organic and bio-N fertilizers on growth, yield and fruit quality of sweet pepper. Journal of Applied Sciences Research . 8 (8):39213922.

El-Hifny, I .M and M.A. El-Sayed . 2011. Response of sweet pepper plant growth and productivity to application of ascorbic acid and biofertilizers under saline conditions. Australian Journal of Basic and Applied Sciences, 5(6): 1273-1283.

Glaser .A and C. Biggs. 2010. An Introduction to Statistical Methods in GenStat. VSN International, Hemel Hempstead, UK.

Jarak, M., S. Duric, and B. Dordevic. 2010. Benefits of inoculation with Azotobacter in the growth and production of tomato and pepers. Matica srpska Journal for Natural Sciences, 119: 71-76.

Lalitha, M ., M. Karunakar Babu., C. Ravi sankar and Y. Ashoka Rani. 2004 . Effect of bio-regulation on chlorophyll content and keeping quality of betelvine (Piper betle L.) Andhra Agric .J ,51(1-2): 165-71.

Matlob, A. N., I. Sultan and K. Abdoul. 1989. Vegetable Production, Part Two, University of Mosul - College of Agriculture and Foresty Mousel university publications

Meena, M. L., V.S. Gehlot ., D.C. Meena., S. Kishor., S. K. S. Kumar and J.K . Meena . 2017. Impact of biofertilizers on growth, yield and quality of tomato (Lycopersicon esculentum Mill.) cv. Pusa Sheetal. Journal of Pharmacognosy and Phytochemistry . 6(4): 1579-1583

Minnotti , P.L., D.E. Halseth and J.B. Sieczka. 1994. Chlorophyll measurement to assess the nitrogen status of potato varieties. Hortscience.J. 29(12): 1497-1500.

Mirzakhani, M., M.R. Ardkani., A. Aeene Band., F. Rejali and A.H. Shirani Rad. 2009. Response of spring safflower to co-inoculation with Azotobacter chroococcum and Glomus intraradices under different levels of nitrogen and phosphorus. American J. Agricultural and Biological Sci. 3: 255-261.

Othman, J. Y. 2007. Effect of using organic fertilizers on growing and yield of potatoes as a contribution to clean organic production. MSc. thesis . faculty of Agriculture . Horticulture department. October University . Syrian Arab Republic. P.68 
Saeed, F. H., M. A Hadi and D. H. Kazem.2014. The Detection of Auxin and Cytokine Hormons in Leachate Growth of Some Biogenic Fertilizers. 1st National Women's Scientific Conference (Special Issue): 186-192.

Saeed, F. H. 2015. Integrated Management of Chemical, Organic and Biological Fertilizers and Their Impact on the Growth and Productivity of Some Genotypes of Cucumber Plant. Ph.D Thesis. Horticulture and Gardening Engineering Department / College of Agriculture - University of Baghdad. Iraq .138.

Saharan,B.S and V. Nehra.2011. Plant growth promoting Rhizobacteria: A critical review. Life Sciences and Medicine Research,J. (21) p:1-29

Salhia, B. M. 2010.The effect of Azotobacter chroococcum as nitrogen biofertilizer on the growth and yield of Cucumis Sativus, MS.Thesis of Biological Sciences / Botany The Islamic University, Gaza.

Shams, A.S. 2003. Response of sweet pepper crop to organic and biofertilizer application. Master thesis. Faculty of Agric. Moshtohor, Zagazing Univ.pp: 158

Shashi, K., M . Kumar ., R. kumar and M. Raghav . 2018. Effect of biofertilizers on growth and yield of tomato (Lycopersicon esculentum Mill). International Journal of Current Microbiology and Applied Sciences 7 (2), 2542- 2545.

Taiz, L and E. Zeiger . 2010. Plant Physiology, $5^{\text {Th }}$ end. Sinauer, Sunderland, Massachussetts.USA.

Tekalign, T and S.P. Hammes. 2005. Growth and biomass production in potato grown in the hot tropics as influenced by paclobut razel . Plant Growth Regulation. Springer Netherland 45(1): 37- 46.

Tosic, I., Z. Golic and A. Radosavac.2016. Effects of the application of biofertilizers on the microflora and yield of lettuce (Lactuca sativa L.). Acta Agriculturae Serbica, , 21 (42): 91-98

Zehra Khan, H., S. Tiyagi., I. Mahmood and R. Rizvi . 2012. Effect of N. fertilization, organic matter, and biofertilizers on the growth and yield of chilli in relation to management of plant parasitic nematodes. Turk J. Bot., 36 : 73-81. 